\title{
Analisis Teknis dan Ekonomis Pembangkit Listrik Tenaga Surya Off-grid Menggunakan Software PVSyst untuk Usaha Mikro Kecil dan Menengah (UMKM) Coffeeshop Remote Area
}

\author{
Jaka Windarta ${ }^{1,2 *}$, Susatyo Handoko ${ }^{2}$, Khilmi Nafadinanto Irfani ${ }^{2}$, Sunan Muqtasida Masfuha ${ }^{2}$, \\ Candra Halim Itsnareno ${ }^{2}$ \\ ${ }^{1}$ Magister Energi Sekolah Pascasarjana, Universitas Diponegoro, \\ ${ }^{2}$ Departemen Teknik Elektro Fakultas Teknik, Universitas Diponegoro, \\ Jl. Prof. Soedarto, SH, Kampus UNDIP Tembalang, Semarang, Indonesia 50275
}

\begin{abstract}
Abstrak
Distribusi listrik dari Perusahaan Listrik Negara (PLN) belum tentu mencapai daerah daerah terpencil, sehingga daerah tersebut memerlukan sumber listrik alternatif seperti Pembangkit listrik Tenaga Surya (PLTS). Penelitian kali ini memiliki tujuan untuk merancang dan menganalisis PLTS Off-grid skala kecil dengan studi kasus UMKM Coffeeshop ditinjau dari analisis teknis dan ekonomi. Metode penelitian yang digunakan adalah dengan melakukan perbandingan dengan menggunakan desain 2 merk panel surya kapasitas 720Wp dan 2 merk baterai kapasitas 160Ah menggunakan software PVSyst 7.0. Dari hasil simulasi didapatkan jumlah energi tersuplai paling banyak pada variasi 3 sebesar 674,51 kWh/tahun. Selain itu dilakukan analisis ekonomi dengan tujuan untuk membandingkan sisi ekonomis PLTS dengan alternatif sumber listrik lain seperti genset dan penggunaan baterai dengan charging dari PLN. Berdasarkan simulasi software RetScreen, nilai Net Present Value (NPV) pada semua variasi diperoleh nilai negatif $(<0)$, akan tetapi penggunaan PLTS off-grid adalah yang paling menguntungkan jika dibandingkan dengan penggunaan genset atau sumber listrik baterai dengan pengisian daya dari PLN.
\end{abstract}

Kata kunci: PLTS; off-grid; remote area; PVSyst; RetScreen

\begin{abstract}
[Title: Technical and economical analysis of off-grid solar power plant using pvsyst software for micro small and medium enterprice (msme) coffeeshop remote area] The distribution of electricity from PLN certainly reaches remote areas, so these areas require alternative sources of electricity such as solar power plants. This study aims to design and analyze the potential of small-scale off-grid PV mini-grid in terms of engineering and economics. The research method used is a simulation on PVSyst 7.0 software with four variations of the main components, namely solar panels and batteries. The research results were obtained based on four variations made, namely a 720Wp panel, a 24V 150Ah battery, and an $800 \mathrm{~W}$ inverter. This design will produce electrical energy of approximately $2 \mathrm{kWh} / \mathrm{kWp} /$ day. The purpose of the economic analysis is to compare the economic side of PLTS with other alternative sources of electricity such as generators and the use of batteries with charging from PLN. Based on the RetScreen simulation software, the NPV values for all variations were negative $(<0)$. Thus all systems are considered economically unfeasible and do not provide benefits. However, the PLTS Off-Grid option is the most profitable compared to generators or battery power sources with PLN charging.
\end{abstract}

Keywords: solar power plant; off-grid system; remote area; PVSyst; RetScreen

${ }^{*}$ Penulis Korespondensi.
E-mail: jakawindarta@lecturer.undip.ac.id

\section{Pendahuluan}

Pertumbuhan permintaan listrik diproyeksikan akan mengalami peningkatan hingga 9 kali lipat dari semula 254,6 TWh saat 2018 menjadi $1.918 \mathrm{TWh}$ pada 2050. Selama periode 2018-2050 permintaan energi 


\section{TEKNIK, 42 (3), 2021, 291}

listrik mencatatkan laju peningkatan sebesar $6,5 \%$ per tahun, dan memiliki pola yang relatif sama. Porsi permintaan listrik terbesar ada pada sektor rumah tangga, lalu pada industri dan diikuti komersil, transportasi, dan sektor lainnya. Potensi energi baru terbarukan Indonesia yang cukup besar ditargetkan dapat memenuhi rencana bauran energi primer tersebut (Dewan Energi Nasional, 2019). Dengan tingkat radiasi rata-rata/hari di Indonesia yang mencapai 4,80 $\mathrm{KWp} / \mathrm{m} 2 /$ hari, dimana ini merupakan kategori yang relatif tinggi menjadikan energi surya pilihan potensial terbaik yang dapat dimanfaatkan hingga skala rumah tangga (kecil). PLTS merupakan pembangkit listrik yang fungsional dan fleksibel sehingga dapat mudah diaplikasikan pada tempat-tempat dengan paparan sinar matahari yang cukup. PLTS dapat dengan mudah diaplikasikan pada atap konstruksi rumah, caravan, bus, atau bahkan mobil tanpa mengganggu kegiatan produksi dan lingkungan sekitar.

Atas dasar tersebut penggunaan PLTS merupakan langkah strategis yang dapat dilakukan untuk alternatif penggunaan listrik pada UMKM yang berada pada remote area tanpa jangkauan listrik. Dengan memanfaatkan ruang yang ada, penggunaan panel surya PLTS menjadi salah satu pilihan pemanfaatan energi terbarukan yang ramah lingkungan pada skala kecil (UMKM). Penggunaan energi terbarukan ini akan berkontribusi menurunkan efek pemanasan global walaupun belum terlalu signifikan.

\section{Bahan dan Metode \\ 2.1 Pembangkit Listrik Tenaga Surya}

Pembangkit Listrik Tenaga Surya atau PLTS merupakan pembangkit listrik yang memanfaatkan sumber energi sinar matahari. PLTS menggunakan sel surya pada panel untuk mengubah energi radiasi yang diperoleh dari sinar matahari atau foton dan mengubahnya menjadi energi listrik. Lapisan silikon murni dan bahan semikonduktor merupakan penyusun utama dari panel surya. PLTS termasuk pembangkit ramah lingkungan, tidak menghasilkan polusi maupun limbah berbahaya bagi lingkungan. Radiasi matahari, suhu sel surya, orientasi panel surya, dan shadow leverages merupakan faktor-faktor yang mempengaruhi efisiensi daya keluaran sel surya (Ramadhani, 2018).

\subsection{Analisis Teknis}

Analisis teknis dilakukan berdasarkan kapasitas PLTS yang dirancang, pemanfaatan dan penentuan spesifikasi komponen, orientasi panel, serta daya yang dihasilkan. Daya dihasilkan PLTS dipengaruhi oleh beberapa faktor antara lain radiasi sinar matahari di UMKM Coffeeshop, kemiringan panel surya dan arahnya, sinar matahari, suhu, dan kinerja teknis masing-masing komponen yang digunakan (Shrivastava dkk., 2021). Untuk menentukan kelayakan teknis PLTS menggunakan rasio performa yang ditunjukkan dalam nilai prosentase. Nilai ini membandingkan total daya yang dapat dihasilkan sistem serta nilai rugi-rugi energi dengan nilai pada saat sistem PLTS beroperasi saat kondisi standart test condition (STC) (Ma dkk., 2017). Rugi-rugi pada sistem pembangkit listrik tenaga surya tergantung oleh efisiensi spesifikasi panel, suhu, dan efisiensi spesifikasi inverter (Pujawan, 2009).

\subsection{Analisis Ekonomi Teknik}

Analisis ekonomi teknik bertujuan untuk menilai kelayakan investasi suatu proyek dengan mengkaji alternati-alternatif paling menguntungkan. Nilai investasi teknik memiliki umur ekonomis dalam satuan tahun. Sejalan dengan hal itu, nilai mata uang berfluktuasi dari waktu ke waktu sehingga memiliki nilai yang tidak sama. Oleh karenanya dibutuhkan proses ekuivalensi nilai mata uang (Bagaskoro dkk., 2019)

Untuk analisis ekonomi teknik digunakan persamaan 1-3 untuk membantu dalam perhitungan.

$$
\begin{aligned}
& P W B=\sum_{t=0}^{n} C b_{t}(F B P)_{t} \\
& P W C=\sum_{t=0}^{n} C c_{t}(F B P)_{t} \\
& N P V=P W B-P W C
\end{aligned}
$$

Dimana $\mathrm{Cb}$ adalah Cash flow benefit, $\mathrm{Cc}$ adalah Cash flow cost, FBP adalah Faktor Bunga Present, t adalah periode waktu, dan $\mathrm{n}$ adalah umur investasi. Dengan PWB merupakan Present Worth Benefit, kemudian PWC adalah nilai Present Worth Cost, dan NPV adalah nilai Net Present Value.

\subsection{Metode penelitian}

Penelitian ini menggunakan alat bantu software PVSYst untuk menganalisis secara teknis dan software RetScreen untuk menganalisis secara ekonomis. Diagram alir penelitian ditunjukkan pada Gambar 1.

Pada Gambar 1 dijelaskan metodologi penelitian, dimulai dari (1) pendalaman teori tentang PLTS, (2) pengambilan data pada UMKM Coffeeshop, (3) merancang spesifikasi minimum sistem PLTS, (4) melakukan simulasi menggunakan perangkat lunak PVSYst, (5) menganalisis secara teknis sistem yang telah dirancang, (6) melakukan analisis ekonomi menggunakan perangkat lunak retscreen, (7) pemilihan sistem terbaik dari segi analisis teknis dan ekonomis untuk diaplikasikan, (8) simpulan dari hasil penelitian.

\section{Hasil dan Pembahasan \\ 3.1 Profil beban harian pada UMKM Coffeeshop}

Lokasi yang dijadikan penelitian adalah Angka Coffee, Tembalang secara astronomis terletak pada koordinat -7.068564888359462, 110.44029635468642. Lokasi UMKM Coffeeshop terlihat pada Gambar 2.

Berdasarkan hasil survey lokasi secara langsung didapatkan data penggunaan beban pada Tabel 1 . Berdasarkan Tabel 1 data profil beban harian dapat 
TEKNIK, 42 (3), 2021, 292

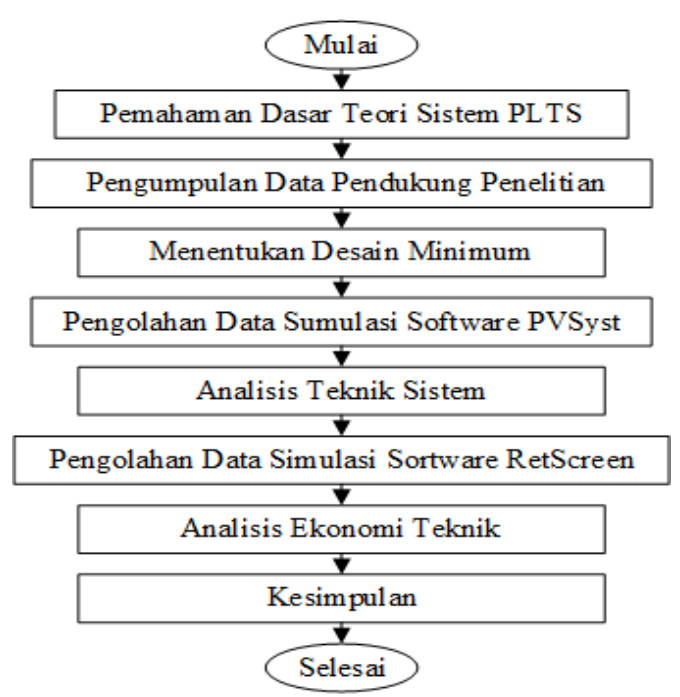

Gambar 1. Diagram alir penelitian

direpresentasikan dalam bentuk grafik dengan parameter per jam seperti pada Gambar 3.

\subsection{Iradiasi pada UMKM Coffeeshop}

Data iradiasi pada lokasi UMKM Coffeeshop ditunjukkan pada Tabel 2 (The Joint Research Centre, 2021).

\subsection{Jenis Sistem}

Sistem PLTS yang akan digunakan pada UMKM Coffeeshop adalah sistem off-grid dengan mempertimbangkan pengguna UMKM yang memiliki mobilitas tinggi menggunakan caravan.

\subsection{Rancangan sistem}

Baterai (Louie, 2018) yang akan digunakan menggunakan sistem 24V dengan DoD 50\%. Daya baterai dihitung menggunakan persamaan 4 , sedangkan kebutuhan baterai dihitung menggunakan persamaan 5 .

Daya baterai:

$$
\begin{aligned}
& =\frac{\text { Beban harian (Wh) }}{\text { Ef Anwerter (\$6) } x \text { Teg Baterail(V) }} \\
& =1892 / 0.95 \times 24 \\
& =82 \mathrm{Ah}
\end{aligned}
$$

Tabel 1. Data profil beban harian pada UMKM Coffeeshop

\begin{tabular}{llllll}
\hline No. & $\begin{array}{l}\text { Alat } \\
\text { Elektronik }\end{array}$ & Jumlah & $\begin{array}{l}\text { Daya } \\
\text { (Watt) }\end{array}$ & $\begin{array}{l}\text { Total } \\
\text { Daya } \\
\text { (Watt) }\end{array}$ & $\begin{array}{l}\text { Total } \\
(\text { Wh) }\end{array}$ \\
\hline 1 & Pemanas air & 1 & 300 & 300 & 2 \\
2 & Grinder Kopi & 1 & 140 & 140 & 2 \\
3 & Router & 1 & 15 & 15 & 15 \\
4 & Lampu A & 8 & 6 & 48 & 8 \\
5 & Lampu B & 1 & 13 & 13 & 6 \\
6 & Lampu C & 1 & 3 & 3 & 10 \\
7 & Kipas angin & 3 & 30 & 90 & 4 \\
8 & Speaker & 1 & 20 & 20 & 3 \\
& Total & & & $\mathbf{6 2 9}$ & \\
\hline
\end{tabular}

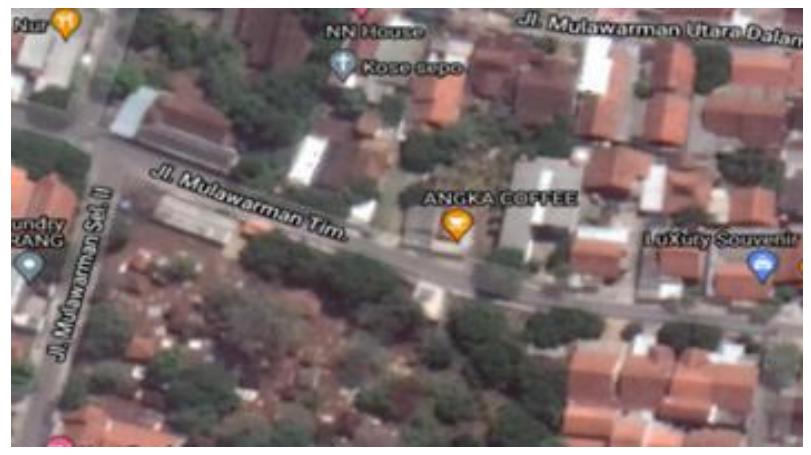

Gambar 2. UMKM Coffeeshop UMKM Coffeeshop "Angka Coffe"

Kebutuhan baterai:

$$
\begin{aligned}
& =\text { Hari otonom } x \text { Beban bat. } x \frac{1}{D O D} \\
& =1 \times 83 \times 1 / 0,5 \\
& =164 \mathrm{Ah}
\end{aligned}
$$

Adapun untuk panel surya (Louie, 2018), pada UMKM Coffeeshop dirancang untuk efektivitas penyinaran paling rendah 3,08 jam. Daya panel dihitung menggunakan Persamaan 6.

$$
\begin{aligned}
& =\frac{\text { Beban harian (Wh) }}{\text { Jam penyinaran (h) } x \text { ffinverter }} \\
& =1892 / 3,08 \times 0,95 \\
& =646 \mathrm{Wp}
\end{aligned}
$$

Kapasitas minimum yang dibutuhkan pada perancangan adalah baterai 24V 160Ah, panel surya 646 Wp. Pada simulasi akan digunakan baterai $12 \mathrm{~V} 160 \mathrm{Ah} \mathrm{x}$ 2 buah dan $12 \mathrm{~V}$ 80Ah x 4 buah, kemudian panel surya sebesar $120 \mathrm{Wp}$ x 6 buah, dan $360 \mathrm{Wp}$ x 2 buah.

\subsection{Perbandingan Komponen Utama PLTS}

Pada perancangan PLTS ini ada 4 komponen utama yang akan dipertimbangkan dalam merancang sistem PLTS off-grid, diantaranya adalah panel surya, baterai, inverter, dan solar charge controller. Komponen yang akan dikombinasikan adalah panel surya dengan baterai dengan konfigurasi sesuai pada Tabel 3.

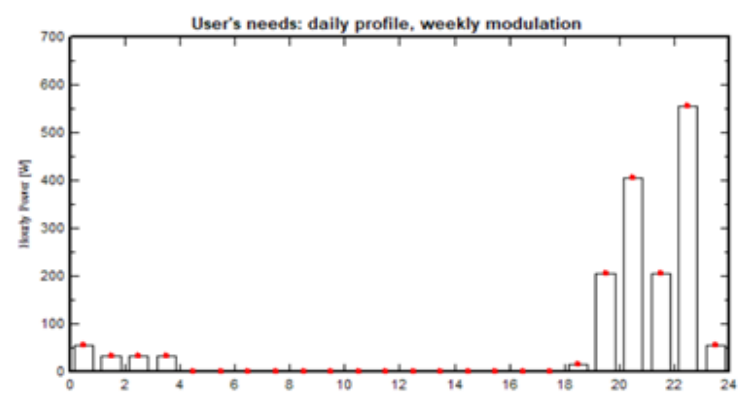

Gambar 3. Grafik penggunaan beban harian pada UMKM Coffeeshop 


\section{TEKNIK, 42 (3), 2021, 293}

Tabel 2. Iradiasi pada UMKM Coffeeshop

\begin{tabular}{|c|c|c|c|}
\hline Bulan & $\begin{array}{c}\text { Iradiasi } \\
\text { Efektif } \\
\left(\mathbf{k W h} / \mathbf{m}^{2} / \text { hari }\right)\end{array}$ & $\begin{array}{c}\text { Suhu } \\
\left({ }^{0} \mathrm{C}\right)\end{array}$ & $\begin{array}{c}\text { Kec. } \\
\text { Angin } \\
(\mathbf{m} / \mathbf{s})\end{array}$ \\
\hline Januari & 3,12 & 25.2 & 2.59 \\
\hline Februari & 3,97 & 25.2 & 1.42 \\
\hline Maret & 3,85 & 24.9 & 2.06 \\
\hline April & 5,18 & 25.7 & 1.76 \\
\hline Mei & 4,90 & 25.2 & 2.65 \\
\hline Juni & 6,09 & 23.9 & 2.82 \\
\hline Juli & 6,34 & 235 & 3.04 \\
\hline Agustus & 6,14 & 23.9 & 3.11 \\
\hline September & 5,96 & 25.3 & 2.99 \\
\hline Oktober & 5,35 & 26.7 & 2.75 \\
\hline November & 3,76 & 27.0 & 2.37 \\
\hline Desember & 3,08 & 26.3 & 1.42 \\
\hline
\end{tabular}

\subsection{Simulasi}

Dalam melakukan simulasi perancangan PLTS Studi Kasus Angka Coffee menggunakan perangkat lunak PVSyst (Shrivastava dkk., 2021), dibutuhkan data-data teknis yang akan berpengaruh pada hasil simulasi dengan menggunakan perangkat lunak. Beberapa faktor yang akan mempengaruhi output/hasil simulasi PLTS diantaranya adalah potensi matahari, nilai irradiasi, temperatur lokasi, kecepatan angin, posisi dan orientasi panel surya, spesifikasi komponen, serta data beban harian pada objek pemasangan. Pada simulasi juga akan ditampilkan besaran daya listrik yang diproduksi, besar daya listrik yang dialirkan ke beban pada lokasi, serta rugi-rugi sistem. Perancangan akan dilakukan menggunakan tipe penyangga tetap di atas atap caravan seperti pada Gambar 4.

\subsection{Hasil Simulasi}

Setelah menginput seluruh data yang dibutuhkan pada simulasi perancangan PLTS ini, simulasi pada PVSyst dapat dijalankan. Hasil simulasi PLTS pada UMKM Coffeeshop Angka didapatkan hasil pada Tabel 4.

Tabel 4 menunjukkan variasi 1 menghasilkan jumlah produksi energi tahunan (E_avail) sebesar 1022 $\mathrm{kWh}$, tingkat pemenuhan energi (solfrac) $99,9 \%$, energi yang dapat digunakan pengguna (E_User) sebesar 674,12

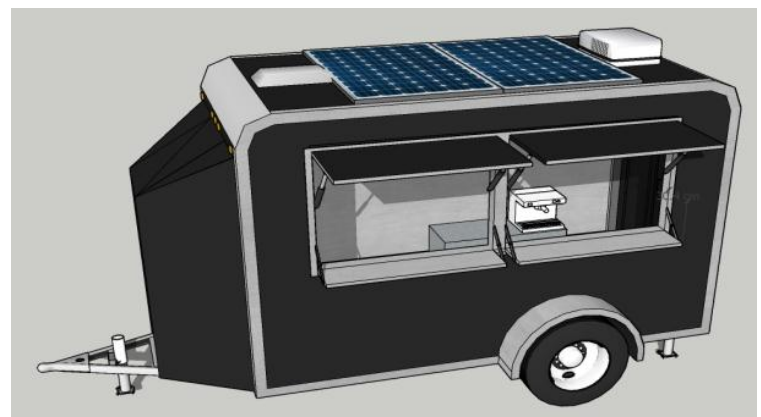

Gambar 4. Visualisasi objek penelitian
Tabel 3. Alternatif konfigurasi komponen PLTS

\begin{tabular}{ccc}
\hline Variasi & Panel Surya & Baterai \\
\hline \multirow{2}{*}{1} & 6 modul seri-paralel & 2 baterai seri \\
& Sunasia 120Wp & Inpowers 12V 160Ah \\
2 & 6 modul seri-paralel & 4 baterai seri-paralel \\
& Sunasia 120Wp & Kijo 12V 80 Ah \\
3 & 2 modul paralel & 2 baterai seri \\
& Canadian 360 Wp & Inpowers 12V 160Ah \\
4 & 2 modul paralel & 4 baterai seri-paralel \\
& Canadian 360 Wp & Kijo 12V 80 Ah \\
\hline
\end{tabular}

$\mathrm{kWh}$, dan performance ratio (PR) 0,502. variasi 2 menghasilkan jumlah produksi energi tahunan (E_avail) sebesar $1022 \mathrm{kWh}$, tingkat pemenuhan energi (solfrac) $99,7 \%$, energi yang dapat digunakan pengguna ( $E_{-}$User) sebesar $672,9 \mathrm{kWh}$, dan performance ratio $(\mathrm{PR}) 0,501$. variasi 3 menghasilkan jumlah produksi energi tahunan (E_avail) sebesar $1084 \mathrm{kWh}$, tingkat pemenuhan energi (solfrac) $100 \%$, energi yang dapat digunakan pengguna (E_User) sebesar $674,51 \mathrm{kWh}$, dan performance ratio(PR) 0,502. variasi 4 menghasilkan jumlah produksi energi tahunan (E_avail) sebesar $1084 \mathrm{kWh}$, tingkat pemenuhan energi (solfrac) 99,9\%, energi yang dapat digunakan pengguna ( $E \_U$ ser $)$ sebesar $674,24 \mathrm{kWh}$, dan performance ratio(PR) 0,502 .

\subsection{Analisis Teknis}

Berdasarkan data yang didapat pada Tabel 4, jumlah energi listrik yang diproduksi panel surya pada Variasi 1 dan 2 adalah $1022 \mathrm{kWh} /$ Tahun, sedangkan pada simulasi dengan Variasi 3 dan 4 jumlah energi listrik yang dihasilkan adalah $1084 \mathrm{kWh} /$ Tahun. Nilai energi STC memiliki perbedaan yang diakibatkan dari perbedaan luas permukaan serta perbedaan efisiensi dari masing-masing panel surya, pada sistem PLTS variasi 1 dan 2 digunakan panel surya merk Sunasia (120Wp x 6) yang memiliki efisiensi sebesar $17 \%$ dan luas area $3,6 \mathrm{~m}^{2}$. Kemudian pada sistem PLTS variasi 3 dan 4 menggunakan panel surya merk Canadian Solar (360Wp x 2) yang memiliki efisiensi sebesar $18,5 \%$ dan luas $4 \mathrm{~m}^{2}$. Sehingga dapat disimpulkan semakin besar luasan permukaan panel dan semakin besar efisiensi memiliki efek yang semakin baik (King dkk., 2002). Efisiensi juga dipengaruhi oleh tipe panel surya yang digunakan. Jenis panel surya monocrystalline menggunakan bahan silikon yang lebih besar konsentrasinya dibanding dengan tipe polycrystalline. Hal ini berpengaruh pada efisiensi panel yang lebih besar pada jenis monocrystalline. Kemudian untuk spesifikasi sama pada nominal daya (Wp), jenis monocrystalline memiliki luasan permukaan panel yang lebih sedikit jika dibanding jenis polycrystalline (Harrouni, 2008).

Jumlah energi yang dapat tersuplai ke pengguna pada variasi 1 sebesar $674,12 \mathrm{kWh}$, variasi 2 sebesar $672,9 \mathrm{kWh}$, variasi 3 sebesar $674,51 \mathrm{kWh}$ dan pada 


\section{TEKNIK, 42 (3), 2021, 294}

variasi 4 sebesar $674,24 \mathrm{kWh}$. Terdapat sedikit perbedaan energi yang dapat disuplai sistem ke pengguna. Ini disebabkan karena baterai yang digunakan memiliki spesifikasi yang sama, sehingga perbedaan energi listrik yang dapat disuplai memiliki nilai yang relatif sama. Jumlah energi tersuplai terbesar ada pada Variasi 3 yaitu sebesar 674,51 kWh.

Tingkat pemenuhan energi pada variasi 1 sebesar 99,9\%, pada variasi 2 sebesar 99,7\%, pada variasi 3 sebesar $100 \%$, pada variasi 4 sebesar $99,9 \%$. Tingkat pemenuhan energi paling besar terdapat pada variasi 3 yaitu sebesar $100 \%$. Nilai ini berpengaruh (berbanding terbalik) terhadap jumlah kekurangan energi listrik (E_miss). Semakin besar tingkat pemenuhan energi semakin kecil nilai kekurangan energi, maka dari itu tingkat pemenuhan energi $100 \%$ berarti sistem PLTS dapat menyuplai seluruh kebutuhan beban pengguna tanpa kekurangan energi yang signifikan.

PR ratio pada setiap variasi memiliki nilai yang tidak jauh berbeda. Pada variasi 1 sebesar 0,501. Pada variasi 2 sebesar 0,501. Pada variasi 3 sebesar 0,502. Kemudian pada variasi 4 sebesar 0,502. Rasio performa sistem PLTS memiliki nilai yang dapat dikategorikan cukup (Rajashekar \& Naganagouda, 2018). Nilai performa rasio untuk sistem off-grid berskisar antara 0,4 hingga 0,6.

Pada seluruh variasi sistem PLTS, terdapat energi tidak terpakai (E_unused) yang cukup signifikan, hal ini disebabkan karena panel surya yang digunakan mengacu pada tingkat penyinaran terendah (3,08 kWh/m2/day) pada bulan Desember. Selain itu, hal ini juga disebabkan karena kapasitas baterai yang terlah terisi penuh.

\subsection{Analisis Ekonomi}

Sistem yang akan dirancang pada UMKM Coffeeshop, akan ditinjau kelayakan ekonomi dan dipilih sesuai dengan hasil perhitungan nilai Net Present Value (NPV). Biaya total investasi, biaya penghematan energi listrik, biaya operasional, discount rate, dan nilai inflasi akan mempengaruhi hasil simulasi. Sebelum menentukan total biaya investasi, peneliti melakukan survei baik pada toko offline di area Kota Semarang, maupun pada toko online di berbagai e-commerce di Indonesia. Hal yang berpengaruh lainya adalah nilai discount rate dan nilai inflasi yang peneliti dapatkan melalui laman resmi Bank Indonesia (Bank Indonesia, 2021).

UMKM Coffeeshop ini adalah remote area, alternatif sumber listrik yang memungkinkan sebagai suplai adalah PLTS, Genset, dan Penggunaan baterai dengan charging dari listrik PLN. Penelitian ini akan membandingkan tiga alternatif ini dari sisi ekonomisnya.

\section{A. PLTS}

Biaya investasi untuk masing-masing komponen pada perancangan sistem PLTS dapat dilihat pada Tabel 5. Berdasarkan Tabel 5 biaya investasi untuk variasi 1 sebesar Rp 17.550.000, variasi 2 sebesar Rp 18.550.000, variasi 3 sebesar Rp 17.550.000, sedangkan variasi 4 sebesar Rp 18.550.000.

Selama operasional PLTS, dibutuhkan biaya operasional dan pemeliharaan untuk sistem PLTS. Nilai ini didefinisikan sebesar 1-2\% dari total biaya investasi awal sistem PLTS, kemudian ditambah biaya penggantian baterai selama masa proyek (Windarta, dkk., 2019), sehingga biaya operasional per tahun yang dibutuhkan sistem PLTS variasi 1, variasi 2, variasi 3, dan variasi 4 ditunjukkan pada Tabel 6 .

Penghematan energi listrik merupakan perhitungan penghematan secara linier dari awal hingga akhir proyek PLTS dijalankan. Penghematan energi listrik diperoleh dari jumlah energi yang disuplai ke beban untuk memenuhi kebutuhan energi listrik sehari-hari UMKM Coffeeshop. Penghematan energi listrik yang dihasilkan sistem PLTS variasi 1, variasi 2 , variasi 3 , dan variasi 4 setiap tahun dapat dilihat pada Tabel 7 .

Berdasarkan hasil simulasi pada software RetScreen didapatkan nilai NPV pada setiap rancangan variasi sistem PLTS sesuai dengan Tabel 8. Nilai NPV juga dapat dihitung menggunakan Persamaan 1-3.

Pada Tabel 9 ditunjukkan nilai NPV setiap Rancangan variasi sistem PLTS memiliki nilai negatif atau kurang dari 0 . Sehingga didapatkan kesimpulan bahwa investasi PLTS untuk masing-masing variasi tidak layak secara ekonomis jika hanya mengacu pada nilai negatif NPV

\section{B. Genset}

Genset yang digunakan sesuai data beban di UMKM Coffeeshop adalah genset dengan daya 1KVA. Tabel 10 menunjukkan biaya investasi penggunaan genset. Berdasarkan dari hasil perhitungan dengan Persamaan 4.

$$
S=K \times P \times T
$$

dimana $\mathrm{S}$ adalah bahan bakar yang diperlukan per hari (liter), K merupakan faktor ketetapan penggunaan bahan bakar per kilowatt per jam (sebesar 0.21), P adalah daya genset (KVA), dan T adalah waktu (jam).

Didapatkan penggunaan bahan bakar dalam sehari sebanyak 2,1 liter (Badaruddin, 2015). Harga bensin saat ini adalah Rp7.650. Konsumsi bahan bakar dalam sehari sebesar Rp16.000 dan dalam setahun mencapai Rp5.622.750. Sehingga biaya untuk operasional penggunaan genset per tahun dapat ditunjukkan dalam Tabel 11. 
TEKNIK, 42 (3), 2021, 295

Tabel 4 Hasil simulasi PLTS

\begin{tabular}{|c|c|c|c|c|c|c|c|c|c|c|}
\hline \multirow[t]{2}{*}{ Variasi } & \multirow[t]{2}{*}{ Bulan } & \multicolumn{9}{|c|}{ Balances and result } \\
\hline & & $\begin{array}{l}\text { GlobHor } \\
k W h / m^{2}\end{array}$ & $\begin{array}{l}\text { GlobEff } \\
k W h / m^{2}\end{array}$ & 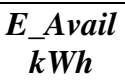 & $\begin{array}{c}\text { EUnused } \\
\boldsymbol{k} W h\end{array}$ & $\begin{array}{c}E_{-} M i s s \\
k W h\end{array}$ & $\begin{array}{c}E \_U s e r \\
k W h\end{array}$ & 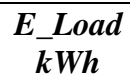 & $\begin{array}{c}\text { SolFrac } \\
\text { ratio }\end{array}$ & $\begin{array}{c}P R \\
\text { ratio }\end{array}$ \\
\hline \multirow[t]{13}{*}{ Variasi 1} & Januari & 124,1 & 120,5 & 68,6 & 11,87 & 0,000 & 52,70 & 52,70 & 1,000 & 0,590 \\
\hline & Februari & 137,4 & 1312 & 75,8 & 19,62 & 0,000 & 52,64 & 52,64 & 1,000 & 0,532 \\
\hline & Maret & 134,1 & 130,5 & 73,8 & 11,72 & 0,000 & 58,28 & 58,28 & 1,000 & 0,603 \\
\hline & April & 155,4 & 151,5 & 86,0 & 25,82 & 0,000 & 56,10 & 56,40 & 1,000 & 0,502 \\
\hline & Mei & 141,1 & 137,2 & 77,8 & 15,53 & 0,000 & 58,28 & 58,28 & 1,000 & 0,574 \\
\hline & Juni & 157,8 & 153,1 & 86,4 & 25,97 & 0,000 & 56,40 & 56,40 & 0,995 & 0,496 \\
\hline & Juli & 173,1 & 168,2 & 94,2 & 31,53 & 0,000 & 58,28 & 58,28 & 1,000 & 0,468 \\
\hline & Agustus & 180,7 & 176,2 & 98,7 & 35,11 & 0,000 & 58,28 & 58,28 & 1,000 & 0,448 \\
\hline & September & 190,5 & 186,3 & 102,7 & 41,91 & 0,000 & 56,40 & 56,40 & 1,000 & 0,411 \\
\hline & Oktober & 199,9 & 195,7 & 109,0 & 46,36 & 0,000 & 58,28 & 58,28 & 1,000 & 0,405 \\
\hline & November & 145,0 & 141,4 & 79,5 & 19,12 & 0,000 & 56,40 & 56,40 & 1,000 & 0,541 \\
\hline & Desember & 126,7 & 123,1 & 70,0 & 14,86 & 0,619 & 52,08 & 52,70 & 1,988 & 0,571 \\
\hline & Tahun & 1865,8 & 1817,8 & 1022,5 & 300,40 & 0,916 & 674,12 & 675,0 & 0,999 & 0,502 \\
\hline \multirow[t]{13}{*}{ Variasi 2} & Januari & 124,1 & 120,5 & 68,6 & 11,26 & 0,000 & 52,67 & 52,67 & 1,000 & 0,590 \\
\hline & Februari & 137,4 & 134,2 & 75,9 & 19,78 & 0,000 & 52,61 & 52,61 & 1,000 & 0,532 \\
\hline & Maret & 134,1 & 130,5 & 73,8 & 11,05 & 0,000 & 5825 & 58,25 & 1,000 & 0,603 \\
\hline & April & 155,4 & 151,5 & 86,1 & 26,78 & 0,850 & 55,52 & 56,37 & 0,985 & 0,496 \\
\hline & Mei & 141,1 & 137,2 & 77,8 & 15,53 & 0,000 & 5825 & 58,25 & 1,000 & 0,573 \\
\hline & Juni & 157,8 & 153,1 & 86,4 & 26,18 & 0,000 & 56,37 & 56,37 & 1,000 & 0,496 \\
\hline & Juli & 173,1 & 168,2 & 94,2 & 32,08 & 0,000 & 5825 & 58,25 & 1,000 & 0,467 \\
\hline & Agustus & 180,7 & 176,2 & 96,7 & 35,57 & 0,000 & 58,25 & 58,25 & 1,000 & 0,448 \\
\hline & September & 190,5 & 186,3 & 102,7 & 42,26 & 0,000 & 56,37 & 58,37 & 1,000 & 0,411 \\
\hline & Oktober & 199,9 & 195,7 & 109,0 & 46,91 & 0,000 & 58,25 & 58,25 & 1,000 & 0,405 \\
\hline & November & 145,0 & 141,4 & 79,5 & 18,96 & 0,000 & 56,37 & 56,37 & 1,000 & 0,540 \\
\hline & Desember & 1287 & 123,1 & 70,0 & 14,42 & 0,000 & 51,82 & 52,67 & 1,984 & 0,568 \\
\hline & Tahun & 1865,8 & 1817,8 & 1022,6 & 301,79 & 1,696 & 672,95 & 674,64 & 0,997 & 0,501 \\
\hline \multirow[t]{13}{*}{ Variasi 3} & Januari & 124,1 & 121,4 & 73,0 & 16,12 & 0,000 & 52,67 & 52,67 & 1,000 & 0,590 \\
\hline & Februari & 137,4 & 135,0 & 80,1 & 23,99 & 0,000 & 52,61 & 52,61 & 1,000 & 0,532 \\
\hline & Maret & 134,1 & 131,4 & 78,5 & 16,05 & 0,000 & 58,25 & 58,25 & 1,000 & 0,603 \\
\hline & April & 155,4 & 152,6 & 91,1 & 30,76 & 0,137 & 56,23 & 56,37 & 0,998 & 0,503 \\
\hline & Mei & 141,1 & 138,3 & 82,8 & 20,46 & 0,000 & 58,25 & 58,25 & 1,000 & 0,573 \\
\hline & Juni & 157,8 & 154,4 & 92,0 & 31,54 & 0,000 & 56,37 & 56,37 & 1,000 & 0,496 \\
\hline & Juli & 173,1 & 169,6 & 100,2 & 37,58 & 0,000 & 58,25 & 58,25 & 1,000 & 0,467 \\
\hline & Agustus & 180,7 & 177,5 & 104,6 & 42,10 & 0,000 & 58,25 & 58,25 & 1,000 & 0,448 \\
\hline & September & 190,5 & 187,4 & 108,7 & 47,78 & 0,000 & 56,37 & 56,37 & 1,000 & 0,411 \\
\hline & Oktober & 199,9 & 196,8 & 114,9 & 52,17 & 0,000 & 58,25 & 58,25 & 1,000 & 0,405 \\
\hline & November & 145,0 & 142,2 & 84,2 & 23,82 & 0,000 & 56,37 & 56,37 & 1,000 & 0,540 \\
\hline & Desember & 126,7 & 124,0 & 74,3 & 18,12 & 0,000 & 52,67 & 52,67 & 1,000 & 0,578 \\
\hline & Tahun & 1865,8 & 1830,6 & 1064,4 & 360,50 & 0,137 & 674,51 & 674,64 & 1,000 & 0,502 \\
\hline \multirow[t]{13}{*}{ Variasi 4} & Januari & 124,1 & 121,4 & 73,0 & 15,69 & 0,000 & 52,70 & 52,70 & 52,70 & 0,590 \\
\hline & Februari & 137,4 & 135,0 & 80,2 & 24,12 & 0,000 & 52,64 & 52,64 & 52,64 & 0,532 \\
\hline & Maret & 134,1 & 131,4 & 78,5 & 15,88 & 0,000 & 58,28 & 58,28 & 58,28 & 0,603 \\
\hline & April & 155,4 & 152,6 & 91,1 & 31,84 & 0,789 & 55,60 & 56,40 & 56,40 & 0,497 \\
\hline & Mei & 141,1 & 138,3 & 82,8 & 20,39 & 0,000 & 58,28 & 58,28 & 58,28 & 0,574 \\
\hline & Juni & 157,8 & 154,4 & 92,0 & 31,87 & 0,000 & 56,40 & 56,40 & 56,40 & 0,496 \\
\hline & Juli & 173,1 & 169,6 & 100,2 & 38,16 & 0,000 & 58,28 & 58,28 & 58,28 & 0,468 \\
\hline & Agustus & 180,7 & 177,5 & 104,7 & 42,45 & 0,000 & 58,28 & 58,28 & 58,28 & 0,448 \\
\hline & September & 190,5 & 187,4 & 108,7 & 48,32 & 0,000 & 56,40 & 56,40 & 56,40 & 0,411 \\
\hline & Oktober & 199,9 & 196,8 & 114,9 & 52,42 & 0,000 & 58,28 & 58,28 & 58,28 & 0,405 \\
\hline & November & 145,0 & 142,2 & 84,2 & 23,86 & 0,000 & 56,40 & 56,40 & 56,40 & 0,541 \\
\hline & Desember & 126,7 & 124,0 & 74,3 & 17,45 & 0,000 & 52,70 & 52,70 & 52,70 & 0,578 \\
\hline & Tahun & 1865,8 & 1830,6 & 1084,5 & 362,44 & 0,798 & 674,24 & 675,04 & 0,999 & 0,502 \\
\hline
\end{tabular}

Keterangan: GlobHor $=$ Global horizontal irradiation, GlobEff $=$ Effictive Global, corr, for IAM and Shadings, EUnused $=$ Unused energy (battery full), E_Avail = Available Solar Energy, E_Miss = Missing energy, E_User = Energy supplied to the user, E_Load = Energy need to the user $($ Load), SolFrac $=$ Solar facrtion $($ EUsed/ELoad), PR = Performance Ratio 


\section{TEKNIK, 42 (3), 2021, 296}

Tabel 5. Perbandingan hasil simulasi PLTS

\begin{tabular}{ccccc}
\hline Variasi & $\begin{array}{c}\text { Energi Listrik Array STC } \\
(\text { E_avail }) \mathbf{k W h}\end{array}$ & $\begin{array}{c}\text { Energi Tersuplai } \\
\left(E_{\_} \text {Load }\right) \mathbf{k W h}\end{array}$ & $\begin{array}{c}\text { Pemenuhan Energi } \\
(\text { Solfrac }) \text { \% }\end{array}$ & PR Ratio \\
\hline 1 & 1022 & 674,12 & 99,9 & 0,501 \\
2 & 1022 & 672,90 & 99,7 & 0,501 \\
3 & 1084 & 674,51 & 100 & 0,502 \\
4 & 1084 & 674,24 & 99,9 & 0,502 \\
\hline
\end{tabular}

Tabel 6. Biaya investasi awal sistem PLTS

\begin{tabular}{|c|c|c|c|c|c|}
\hline Variasi & Nama Komponen & Jumlah & Harga & & Total Harga \\
\hline \multirow[t]{10}{*}{ Variasi 1} & Panel Sunasia $120 \mathrm{Wp}$ & 6 Modul & Rp $\quad 600.000$ & & Rp 3.600 .000 \\
\hline & Solar Charge Controller Epever & 1 Buah & Rp 1.500 .000 & & $\operatorname{Rp} 1.500 .000$ \\
\hline & Baterai Inpowers $12 \mathrm{~V} 160 \mathrm{Ah}$ & 2 Buah & $\operatorname{Rp} 3.500 .000$ & & $\operatorname{Rp} 7.000 .000$ \\
\hline & Inverter $800 \mathrm{~W}$ & 1 Buah & Rp 2.000 .000 & & $\operatorname{Rp} 2.000 .000$ \\
\hline & Penyangga Panel & 1 set & Rp 1.000 .000 & & $\operatorname{Rp} 1.000 .000$ \\
\hline & Pembumian Panel & 1 set & $\mathrm{Rp} \quad 250.000$ & & $\mathrm{Rp} \quad 250.000$ \\
\hline & Kabel & 1 set & Rp $\quad 500.000$ & & $\mathrm{Rp} \quad 500.000$ \\
\hline & Proteksi & 1 set & $\mathrm{Rp} \quad 200.000$ & & $\mathrm{Rp} \quad 200.000$ \\
\hline & Jasa dan lain-lain & $1 \mathrm{set}$ & Rp 1.500 .000 & & $\operatorname{Rp} 1.500 .000$ \\
\hline & & & & Total & Rp 17.550.000 \\
\hline \multirow[t]{10}{*}{ Variasi 2} & Panel Sunasiar $120 \mathrm{Wp}$ & 6 Modul & $\mathrm{Rp} \quad 600.000$ & & Rp 3.600 .000 \\
\hline & Solar Charge Controller Epever & 1 Buah & $\mathrm{Rp} 1.500 .000$ & & $\mathrm{Rp} 1.500 .000$ \\
\hline & Baterai Kijo $12 \mathrm{~V} 80 \mathrm{Ah}$ & 4 Buah & $\mathrm{Rp} 2.000 .000$ & & Rp 8.000.000 \\
\hline & Inverter $800 \mathrm{~W}$ & 1 Buah & $\mathrm{Rp} 2.000 .000$ & & Rp 2.000 .000 \\
\hline & Penyangga Panel & 1 set & $\mathrm{Rp} 1.000 .000$ & & $\operatorname{Rp} 1.000 .000$ \\
\hline & Pembumian Panel & 1 set & $\mathrm{Rp} \quad 250.000$ & & $\mathrm{Rp} \quad 250.000$ \\
\hline & Kabel & 1 set & $\mathrm{Rp} \quad 500.000$ & & Rp 500.000 \\
\hline & Proteksi & $1 \mathrm{set}$ & $\mathrm{Rp} \quad 200.000$ & & $\mathrm{Rp} \quad 200.000$ \\
\hline & Jasa dan lain-lain & 1 set & $\mathrm{Rp} 1.500 .000$ & & Rp 1.500 .000 \\
\hline & & & & Total & Rp 18.550.000 \\
\hline \multirow[t]{10}{*}{ Variasi 3} & Panel Canadian Solar 360Wp & 2 Modul & $\operatorname{Rp} 2.100 .000$ & & Rp 4.200.000 \\
\hline & Solar Charge Controller Epever & 1 Buah & Rp 1.500 .000 & & Rp 1.500 .000 \\
\hline & Baterai Inpowers $12 \mathrm{~V} 160 \mathrm{Ah}$ & 2 Buah & $\mathrm{Rp} 3.500 .000$ & & $\operatorname{Rp} 7.000 .000$ \\
\hline & Inverter $800 \mathrm{~W}$ & 1 Buah & $\mathrm{Rp} 2.000 .000$ & & $\operatorname{Rp} 2.000 .000$ \\
\hline & Penyangga Panel & 1 set & $\operatorname{Rp} 1.000 .000$ & & $\mathrm{Rp} 1.000 .000$ \\
\hline & Pembumian Panel & 1 set & $\mathrm{Rp} \quad 250.000$ & & $\mathrm{Rp} \quad 250.000$ \\
\hline & Kabel & 1 set & $\mathrm{Rp} \quad 500.000$ & & Rp $\quad 500.000$ \\
\hline & Proteksi & 1 set & $\mathrm{Rp} \quad 200.000$ & & $\mathrm{Rp} \quad 200.000$ \\
\hline & Jasa dan lain-lain & 1 set & Rp 1.500 .000 & & Rp 1.500 .000 \\
\hline & & & & Total & Rp 18.150.000 \\
\hline \multirow[t]{10}{*}{ Variasi 4} & Panel Canadian Solar 360Wp & 2 Modul & $\operatorname{Rp} 2.100 .000$ & & Rp 4.200.000 \\
\hline & Solar Charge Controller Epever & 1 Buah & $\operatorname{Rp} 1.500 .000$ & & $\mathrm{Rp} 1.500 .000$ \\
\hline & Baterai Kijo $12 \mathrm{~V} 80 \mathrm{Ah}$ & 4 Buah & $\mathrm{Rp} 2.000 .000$ & & Rp 8.000 .000 \\
\hline & Inverter $800 \mathrm{~W}$ & 1 Buah & $\operatorname{Rp} 2.000 .000$ & & Rp 2.000 .000 \\
\hline & Penyangga Panel & 1 set & $\mathrm{Rp} 1.000 .000$ & & $\operatorname{Rp} 1.000 .000$ \\
\hline & Pembumian Panel & 1 set & $\operatorname{Rp} \quad 250.000$ & & $\mathrm{Rp} \quad 250.000$ \\
\hline & Kabel & 1 set & Rp $\quad 500.000$ & & Rp 500.000 \\
\hline & Proteksi & 1 set & $\mathrm{Rp} \quad 200.000$ & & Rp 200.000 \\
\hline & Jasa dan lain-lain & $1 \mathrm{set}$ & Rp 1.500 .000 & & Rp 1500.000 \\
\hline & & & & Total & Rp 19.150.000 \\
\hline
\end{tabular}

Penghematan energi listrik pada sistem genset diasumsikan sama dengan penghematan PLTS dengan alasan penggunaan beban yang sama. Dengan daya yang dihasilkan diasumsikan $674 \mathrm{kWh} /$ tahun, didapatkan nilai NPV dalam masa proyek 24 tahun sebesar -
Rp173.514.432. Karena nilai NPV bernilai negatif maka investasi pada sistem genset tidak layak untuk dilaksanakan. 


\section{TEKNIK, 42 (3), 2021, 297}

Tabel 7. Biaya operasional sistem PLTS per tahun

\begin{tabular}{cccc}
\hline $\begin{array}{c}\text { Nama } \\
\text { Variasi }\end{array}$ & $\begin{array}{c}\text { O\&M } \\
\text { Komponen }\end{array}$ & $\begin{array}{c}\text { Penggantian } \\
\text { Baterai }\end{array}$ & Total \\
\hline 1 & Rp 160,500 & Rp 875.000 & Rp 1.035.500 \\
2 & Rp 170,500 & Rp 1.000 .000 & Rp. 1.170 .500 \\
3 & Rp 166,500 & Rp 875.000 & Rp. 1.041 .500 \\
4 & Rp 176,500 & Rp 1.000 .000 & Rp. 1.176 .500 \\
\hline
\end{tabular}

Tabel 8. Penghematan sistem PLTS

\begin{tabular}{cccc}
\hline $\begin{array}{c}\text { Nama } \\
\text { Variasi }\end{array}$ & $\begin{array}{c}\boldsymbol{k} \text { Wh / } \\
\text { Tahun }\end{array}$ & Harga & Total Harga \\
\hline 1 & 674,12 & Rp 1.467 & Rp 988.934 \\
2 & 672,90 & Rp 1.467 & Rp 987.144 \\
3 & 674,51 & Rp 1.467 & Rp 989.506 \\
4 & 674,24 & Rp 1.467 & Rp 989.110 \\
\hline
\end{tabular}

Tabel 9. Nilai NPV PLTS variasi 1, 2, 3 dan 4

\begin{tabular}{|c|c|c|c|}
\hline Nama Variasi & PWC & PWB & NPV \\
\hline 1 & Rp 54.268.068 & Rp 35.066.874 & -Rp 19.201.195 \\
\hline 2 & Rp 60.055 .069 & Rp 35.003.411 & -Rp 25.051.658 \\
\hline 3 & Rp 55.080.824 & Rp 35.087 .161 & -Rp 19.993.663 \\
\hline 4 & Rp 60.867 .824 & Rp 35.073.116 & -Rp 25.794.709 \\
\hline
\end{tabular}

Tabel 10. Modal awal penggunaan genset

\begin{tabular}{lccccc}
\hline Nama Komponen & Jumlah & \multicolumn{2}{c}{ Harga } & \multicolumn{2}{c}{ Total Harga } \\
\hline Generator Set & 1 set & \multicolumn{2}{c}{ Rp 5.720.000 } & Rp 5.720.000 \\
Silent 1 KVA & & & & & \\
Kabel & 1 set & Rp & 500.000 & Rp & 500.000 \\
Proteksi & 1 set & Rp & 200.000 & Rp & 200.000 \\
Jasa dan lain-lain & 1 set & Rp & 500.000 & Rp & 500.000 \\
& Total & & & \multicolumn{2}{c}{ Rp 6.920.000 } \\
\hline
\end{tabular}

Tabel 12. Modal awal sistem charging

\begin{tabular}{|c|c|c|c|}
\hline $\begin{array}{c}\text { Nama } \\
\text { Komponen }\end{array}$ & Jumlah & Harga & Total Harga \\
\hline $\begin{array}{l}\text { Charger Baterai } \\
\text { Suoer }\end{array}$ & $1 \mathrm{Buah}$ & Rp 250.000 & Rp 250.000 \\
\hline $\begin{array}{l}\text { Baterai Inpowers } \\
12 \mathrm{~V} 160 \mathrm{Ah}\end{array}$ & 2 Buah & Rp 3.500 .000 & Rp 7.000.000 \\
\hline Inverter $800 \mathrm{~W}$ & $1 \mathrm{Buah}$ & Rp 2.000 .000 & Rp 2.000.000 \\
\hline Kabel & 1 set & Rp 500.000 & Rp $\quad 500.000$ \\
\hline Proteksi & 1 set & Rp 200.000 & Rp $\quad 200.000$ \\
\hline Jasa dan lain-lain & $\begin{array}{l}1 \text { set } \\
\text { Total }\end{array}$ & Rp 500.000 & $\begin{array}{rr}R p & 500.000 \\
R p & \mathbf{1 0 . 4 5 0 . 0 0 0} \\
\end{array}$ \\
\hline
\end{tabular}

Tabel 11. O\&M Penggunaan genset per tahun

\begin{tabular}{ll}
\hline \multicolumn{1}{c}{ Nama Komponen } & Total Harga \\
\hline O\&M Komponen & Rp $r 4.200$ \\
Bahan bakar & Rp 5.622 .750 \\
Total & Rp $\mathbf{5 . 6 8 6 . 9 5 0}$ \\
\hline
\end{tabular}

Tabel 13. O\&M Sistem charging baterai per tahun

\begin{tabular}{ll} 
Nama Komponen & Total Harga \\
\hline O\&M Komponen & Rp 64.200 \\
Bahan bakar & Rp 5.622 .750 \\
Total & Rp 5.686 .950 \\
\hline
\end{tabular}

Tabel 14. Perbandingan nilai NPV dan PWC

\begin{tabular}{ccc}
\hline Nama Variasi & \multicolumn{2}{c}{ NPV } \\
\hline PLTS Variasi 1 & $-\mathrm{Rp}$ & 19.201 .195 \\
PLTS Variasi 2 & $-\mathrm{Rp}$ & 25.051 .658 \\
PLTS Variasi 3 & $-\mathrm{Rp}$ & 19.993 .663 \\
PLTS Variasi 4 & $-\mathrm{Rp}$ & 25.794 .709 \\
Generator & $-\mathrm{Rp}$ & 173.514 .432 \\
Sistem Charging & $-\mathrm{Rp}$ & 46.164 .256 \\
\hline
\end{tabular}

\section{Sistem Charging Baterai dari PLN}

Biaya investasi penggunaan baterai dengan charging dari PLN ditunjukkan pada Tabel 12. Daya yang digunakan untuk charging baterai yaitu sebesar daya beban ditambah rugi-rugi sistem yaitu sekitar 2 KWH per hari. Sehingga biaya untuk operasional penggunaan sistem ini dalam satu tahun dapat ditunjukkan dalam Tabel 13.

Penghematan energi listrik pada sistem genset diasumsikan sama dengan penghematan PLTS dengan alasan penggunaan beban yang sama. Dengan daya yang dihasilkan diasumsikan $674 \mathrm{kWh} / \mathrm{tahun}$, didapatkan nilai NPV dalam masa proyek 24 tahun sebesar -Rp 46.164.256. Karena nilai NPV bernilai negatif maka investasi pada sistem charging tidak layak untuk dilaksanakan.

\section{Perbandingan}

Dari hasil analisis yang didapat untuk semua alternatif yang ada, dapat dibuat perbandingan seperti pada Tabel 14. Berdasarkan Tabel 16, dapat dilihat nilai 


\section{TEKNIK, 42 (3), 2021, 298}

NPV pada setiap alternatif bernilai negatif. Sehingga dapat disimpulkan bahwa semua investasi untuk variasi tidak layak secara ekonomi. Namun PLTS variasi 1 dan 3 merupakan variasi yang paling murah bila dibandingkan dengan alternatif sumber listrik lain.

\section{Kesimpulan}

Sistem pembangkit listrik tenaga surya yang dirancang dalam penelitian ini adalah sistem off-grid. Perencanaan PLTS dibagi menjadi empat variasi yang masing-masing memiliki konfigurasi tersendiri. Kombinasi yang divariasikan adalah panel surya dengan baterai. Alternatif komponen yang akan digunakan masing-masing adalah 2 merk Panel Surya dan 2 merk baterai. Listrik yang dihasilkan dari PLTS berkisar antara 672-675 $\mathrm{kWh}$ per tahun dan masing-masing variasi perencanaan ini dianggap tidak layak karena memiliki nilai NPV kurang 0, namun nilai investasi PLTS ini masih jauh lebih hemat dan murah bila dibandingkan menggunakan sumber listrik genset maupun sistem charging baterai dari PLN. Berdasarkan analisis teknis-ekonomis yang telah dilakukan sebelumnya, investasi yang paling layak adalah variasi pertama dan ketiga karena sama-sama memiliki nilai NPV paling besar yaitu -Rp19.201.195.

\section{Daftar Pustaka}

Badaruddin, B., \& Hardiansyah, F. (2015). Perhitungan Optimasi Bahan Bakar Solar pada Pemakaian Generator Set Di BTS. Jurnal Teknologi Elektro, 6(2), 142512.

Bagaskoro, B., Windarta, J., \& Denis, D. (2019). Perancangan Dan Analisis Ekonomi Teknik Pembangkit Listrik Tenaga Surya Sistem Offgrid Menggunakan Perangkat Lunak Homer Di Kawasan Wisata Pantai Pulau Cemara. Transient: Jurnal Ilmiah Teknik Elektro, 8(2), 152-157.

Bank Indonesia. (2021). Monetary Data Bank Indonesia. Diakses dari dari https://www.bi.go.id/en/ moneter/Contents/Default.aspx, tanggal 02 Juni 2021

Dewan Energi Nasional. (2019). Outlook Energi
Indonesia 2019. Dewan Energi Nasional, 75. https://www.den.go.id/index.php/publikasi/index/ EnergyOutlook

Harrouni, S. (2008). Modeling Solar Radiation at the Earth's Surface: Recent Advances. In Modeling Solar Radiation at the Earth's Surface: Recent Advances (pp. 29-54). Springer Berlin Heidelberg. https://doi.org/10.1007/978-3-540-77455-6_2

King, D. L., Boyson, W. E., \& Kratochvil, J. A. (2002). Analysis of factors influencing the annual energy production of photovoltaic systems. Conference Record of the IEEE Photovoltaic Specialists Conference, 1356-1361. https://doi.org/10.1109/pvsc.2002.1190861

Louie, H. (2018). Energy Poverty: Off-Grid Electrical Systems in Developing Countries. In Off-Grid Electrical Systems in Developing Countries. https://doi.org/10.1007/978-3-319-91890-7_2

Ma, T., Yang, H., \& Lu, L. (2017). Long term performance analysis of a standalone photovoltaic system under real conditions. Applied Energy, 201, $320-331$. https://doi.org/10.1016/j.apenergy.2016.08.126

Pujawan, I. N. (2009). Ekonomi Teknik .Edisi Kedua. Jakarta: PT. Guna Widya.

Ramadhani, B. (2018). Instalasi pembangkit listrik tenaga surya Dos \& Don'ts. Jakarta: Energising Development (EnDev) Indonesia.

Rekhashree, D. J., \& Naganagouda, H. (2018). Study on Design and Performance Analysis of Solar PV Rooftop Standalone and On Grid System Using PVSYST. International Research Journal of Engineering and Technology (IRJET), 5(07).

Shrivastava, A., Sharma, R., Saxena, M. K., Shanmugasundaram, V., \& Rinawa, M. L. (2021). Solar energy capacity assessment and performance evaluation of a standalone PV system using PVSYST. Materials Today: Proceedings

The Joint Research Centre (2021). TMY generator. Diakses dari https://ec.europa.eu/jrc/en/PVGIS/tools/tmy 